\title{
Transition of the Feldstein-Horioka Puzzle
}

\author{
Isamu Ginama $^{{ }^{*}}$, Kazuhiko Hayakawa ${ }^{2}$, Takahiro Kanmei ${ }^{3}$ \\ ${ }^{1}$ Faculty of Economics, Hiroshima University of Economics, Hiroshima, Japan \\ ${ }^{2}$ Faculty of Economics, Hiroshima University, Hiroshima, Japan \\ ${ }^{3}$ Kokushikan University, Tokyo, Japan \\ Email: ^is-gina@hue.ac.jp
}

How to cite this paper: Ginama, I., Hayakawa, K. and Kanmei, T. (2021) Transition of the Feldstein-Horioka Puzzle. Journal of Mathematical Finance, 11, 123-151. https://doi.org/10.4236/jmf.2021.111006

Received: November 25, 2020

Accepted: February 23, 2021

Published: February 26, 2021

Copyright $\odot 2021$ by author(s) and Scientific Research Publishing Inc. This work is licensed under the Creative Commons Attribution International License (CC BY 4.0).

http://creativecommons.org/licenses/by/4.0/ (c) (i) Open Access

\begin{abstract}
Common factor panel methodologies are applied to investment and savings rates in the context of the Feldstein-Horioka puzzle to derive idiosyncratic components of the two variables for OECD countries, Japan, and Indonesia. The idiosyncratic components of the two variables in the national and regional data are analyzed using panel methodologies of unit root and cointegration tests. Bootstrap confidence intervals of the correlation coefficient and the relative variance ratio for the two variables are estimated to ascertain what, if any, relation exists between the mobility and the relative volatility of the two variables. The empirical examinations presented herein suggest that the puzzle is fading in recent times. This paper presents an attempt to alleviate somewhat contradictory views of the plausibility of this important puzzle in international macroeconomics expressed in the existing literature by presenting empirical results demonstrating the existence of the puzzle in one period, and demonstrating the puzzle fading away in the other periods.
\end{abstract}

\section{Keywords}

Bootstrap Confidence Interval, Capital Mobility, Common Factor, Panel Cointegration, Panel Unit Root, Relative Variances

\section{Introduction}

This paper presents analysis of the Feldstein-Horioka puzzle in the following manner: Common factor panel methodologies are applied to investment and savings rates to derive the idiosyncratic components of the two variables for OECD countries, Japan, and Indonesia. Whether the relation between the two variables is statistically significant, or not, is examined using panel unit root and cointegration methods for the idiosyncratic components of the two variables, in contrast to some studies described in the existing literature. Bootstrap confi- 
dence intervals of the correlation coefficient between the two variables are constructed based on the period averages of idiosyncratic components. Mobile capital flows are defined in terms of non-significant correlations between the two variables. The relative volatility of the investment rate is defined as the ratio of the variance of the investment rate to the variance of the savings rate. Bootstrap confidence intervals of the relative variances are estimated using the idiosyncratic components of the two variables to ascertain what, if any, relation exists between the mobility and the volatility of the two variables.

This paper is organized as follows. A brief review of the literature reveals many reports describing the application of panel data methodologies in the field, as presented in the first section. The second section explains the analytical methods used for this study: The common factor panel methodology, the panel unit root and cointegration tests, and the construction of bootstrap confidence intervals to ascertain the correlation coefficient and the relative variances between investment and savings rates.

The concepts of the variables and the data sources are described in section three. Results of panel unit root tests and the panel cointegration tests are presented in Section 4. Estimations of confidence intervals of the correlation coefficient and the variance ratios between investment and savings rates are reported in Section 5. The interpretations of the relation between the relative variances and the capital mobility are described in this section as well. The final section concludes the paper.

\section{Brief Review}

Examples of the literature ${ }^{1}$ [1] describing studies using panel data methodologies to test the F-H puzzle are work by Kitamura et al. [2] using data of 23 OECD countries ${ }^{2}$ for 1960-1989 and by Krol [3] using data of 21 OECD countries for 1962-1990 applying fixed effects panel regression models to estimate the savings coefficient. The savings coefficient became smaller in magnitude than in cross-section regressions that use the period average variables in the earlier literature.

Coiteux and Olivier [4] used panel co-integration to analyze the panel data of 22 OECD countries during 1960-1995, confirming the existence of the F-H puzzle. Jansen [5], in addition to this literature, attributed the low estimates of the savings coefficient in [3] to the inclusion of Luxembourg data among the panel data.

Blanchard and Giavazzi [6] applied a fixed effects panel regression equation with a time-varying savings parameter using data of 22 OECD countries for 1975-2000. Using regression equations for different groups of countries, estimation results for three partitioned time periods of this paper show that, for the $\mathrm{EU}$ and especially for euro-zone countries, the F-H puzzle vanished after the ${ }^{1}$ Apergis and Tsoumas [1] present a survey of a wide range of the available literature related to analyses of the Feldstein-Horioka puzzle.

${ }^{2}$ In some cases, the number of countries of panel data is denoted by $N$ in this paper, such as $N=23$.

${ }^{3}$ The number of observations in time dimension of a panel data is denoted by $T$ herein, as $T=30$. 
mid-1990s.

Coakley et al. [7] analyzed panel data of 12 OECD economies from 1980 through 2000 using a mean group regression approach. The F-H puzzle was not confirmed for OECD economies under the condition that the current account solvency requirement is not satisfied in the short run.

Chakrabarti [8] analyzed a panel dataset for 1960-2000 in terms of multivariate heterogeneous panel co-integration methods. Data of 126 countries showed the existence of the F-H puzzle for various country groups, including OECD countries.

Fouquau et al. [9] estimated the time-varying savings coefficient in the smoothing threshold regression model using panel data of 24 OECD countries for 1960-2000. Explanations for the values of the savings coefficient were made in terms of five factors: economic growth, demography, country openness, country size, and current account balance. The savings coefficient of the countries in the panel tended to decrease over time during the sample period. The savings coefficients of several countries exhibited rapid reduction during the latter half of the 1990s.

Giannone and Lenza [10] presented results showing that the puzzle had faded away during the periods of 1980-89, 1990-98, and 1999-2007 by running factor-augmented panel regressions in which the common factors of investment and savings rates controlled the influences of global shocks.

Byrne et al. [11] analyzed panel data of 21 OECD countries during 1971-2004 for the panel unit root tests allowing cross-sectional dependence (PANIC test reported by Bai and $\mathrm{Ng}$ [12]) and for panel cointegration tests ${ }^{4}$ [13] assuming cross-sectional independence (Pedroni [14]) of common factors and idiosyncratic components of national investment and savings rates. Based on the results that the two components are of $\mathrm{I}(1)$, the possibilities of cointegration between the two variables were tested. Based on the finding of no cointegration relation between the idiosyncratic components, the F-H puzzle was attributed to global components (common factors) in savings and investment comovements.

Younas and Chakraborty [15] pointed out the relation between the respective increments of progress achieved in openness and financial market integration, and the reductions of the savings coefficient in the F-H equation. Data of 99 economically developing and developed countries including OECD countries during 1970-2005 were analyzed using dynamic panel GMM methods.

Costantini and Gutierez [16] used panel data of 21 OECD countries during 1970-2008. PANIC tests ${ }^{5}$ [17] conducted using the two variables revealed common factors of $\mathrm{I}(1)$ and revealed idiosyncratic components of $\mathrm{I}(0)$. Cup-FM panel cointegration tests reported by Bai and Kao $[18]^{6}$ allowing the cross-sectional

\footnotetext{
${ }^{4} \mathrm{Absence}$ of a cointegration relation between investment and savings rates is not contradictory to the current account solvency condition (Bohn [13]).

${ }^{5}$ This test incorporates the cross-sectional dependence to test for unit root in panel data. It is regarded as a "second generation" ([17]) panel unit root test.

${ }^{6}$ This test is regarded as a "second generation" ([17]) panel cointegration test that allows cross-sectional dependence.
} 
dependence on common factors indicated a value of the savings (retention) coefficient ${ }^{7}$ that was significant but very close to zero, from which a negative interpretation was derived for existence of the F-H puzzle.

For 30 EU economies, Katsimi and Zoega [19] applied a 10-year window panel regression method to panel data for 1960-2014. They showed that formation of the EU, especially of the euro zone, negatively affected the savings coefficient.

Ford and Horioka [20] used no empirical method, but did indicate that global financial market integration is not itself a sufficient condition for attaining net capital transfers among countries. For capital transfers across international borders to be perfectly mobile, global goods markets must be integrated. The F-H results are expected to be resilient without this condition being satisfied. Obstfeld and Rogoff [21] and [6] refer to the importance of goods market integration across countries for attaining international capital mobility. Yasutomi and Horioka [22] refer to Adam Smith in the context of the causes of home country biases in investment behaviors for the owners of capital.

Drakos, Kouretas, and Vlamis [23] used panel data of 14 EU countries for 1970-2015. By applying Choi [24] [25] ${ }^{8}$ panel unit root tests with cross-section dependence considered, they found that common factors and idiosyncratic components of the two variables were of I(1). Only common factors were cointegrated in Pedroni [14] tests. Accordingly, the common factor cointegration was interpreted as representing the puzzle.

Ginama, Hayakawa, and Kanmei [26] examined two panel datasets of OECD countries comprising 24 countries during 1968-1996 as dataset I, and 29 countries during 1997-2015 as dataset II by application of the interactive fixed effects common factor panel regression method (Moon and Weidner (MW, hereafter) [27]). The results were consistent with the interpretation that the F-H puzzle existed in period I, but that it ceased to exist in period II. Segmentation of the observation period in the literature corresponds to the mid-1990s, during which two important events of goods markets integration were taking place: EU and euro zone formation.

This paper presents analyses of regional data of Japan and Indonesia in line with earlier reports by Sinn [28] for the US, Bayoumi and Rose [29] for the UK, Thomas [30] for the UK, Germany, and Canada, Yamori [31] and Dekle [32] for Japan, and [26] for Japan, Indonesia, and the Philippines. Nevertheless, no report of the relevant literature describes analysis of regional data among the panel data estimation methods of unit root and cointegration. Intranational capital flows, taking place within a single country, are presumed to occur with no obstacles. Statistically non-significant savings coefficient estimates found from analyses of regional data can therefore serve as an appropriate barometer for the Feldstein-Horioka criterion as an empirical measure of international capital flow mobility.

${ }^{7}$ This coefficient is presented as $\beta$ in Equation (1) in the Methods section.

${ }^{8}$ The original citation of this literature was a reference to work by [25]. 


\section{Methods}

To quantify the degree of international capital mobility, Feldstein and Horioka [33] (F-H, hereinafter) estimated Equation (1) as

$$
(I / Y)_{i}=\alpha+\beta(S / Y)_{i}+\varepsilon_{i},
$$

where $I, S, Y$, and $\varepsilon$ respectively denote investment, savings, gross domestic product (GDP), and an error term for country $i$. Using both 5-year and 15-year savings and investment rate averages, they found that the estimate of $\beta$ (the retention coefficient) was significantly different from zero, but also that it was not significantly different from one. They interpreted this result as demonstrating that capital is not mobile across international borders, despite the general prevailing understanding that international capital markets were well integrated (Frankel, Dooley and Mathieson [34]).

Several criticisms have been made of the F-H interpretation of $\beta$. Positive correlation between investment and savings rates are influenced by the following factors, which make statistical data use obscure for assessing movements of capital flows across international borders: 1 fluctuations over business cycle phases (Feldstein [33] [35], Frankel [30] [36]); 2 government policy reactions to current account imbalances ([32] [36], Summers [30] [31] [37]); 3 economic growth and demographic changes ([32] [36], Obstfeld [38] and [31] [37] [39]); 4 productivity growth, hysteresis of the capital-output ratio, corporate financing friction ([39]); and 5 per-capita wealth, fiscal policy variables, and global shocks (Giannoni and Lenza [10], Iwamoto and Wincoop (IW, hereinafter) [40]).

Estimation of Equation (1) is hindered by these common effects ${ }^{9}$ in measuring capital flow mobility across international frontiers. The simultaneity problem caused by common effects was treated in the literature using methods of instrumental variables (Ginama, Hayakawa, and Kanmei [26], Thomas [30], Yamori [31], Dekle [32], Feldstein-Horioka [33]), using fixed-effects panel regression methods (Kitamura and Fujiki [2], Krol [3] $]^{10}$ ), using auxiliary regression to filter out the influences of common effects (IW [40]), using common-factor augmented regressions ([10]), and using interactive fixed effects common factor panel regression method ([26]).

This paper can be regarded among those with models particularly addressing the components remaining after filtering out common effects from the two variables of investment and savings rates to quantify capital mobility across international borders. The common effects are estimated as common factors in the ${ }^{9}$ Obstfeld [38] argues conceptually that "common factors affecting both saving and investment rates might cause these variables to be highly correlated" (p. 67), but high correlation estimated in this way is not empirical evidence of capital immobility.

${ }^{10} \mathrm{Krol}[3]$ tries to resolve the endogeneity problem with equation (1) using the fixed effects panel regression method. A formal test of whether or not the endogeneity problem exists with the panel data estimation method revealed that the OLS estimation of the model was not adversely affected by the problem. Kitamura and Fujiki [2] demonstrated that the fixed effects panel estimators were always better than the simple pooling model estimators without implementing a formal test of the endogeneity problem. 
common factor panel method. The resulting idiosyncratic components are analyzed using the panel unit root and cointegration models, and using the boot strap confidence interval estimation procedures.

\subsection{Common Factor Panel Model}

Based on results reported by Bai and $\mathrm{Ng}$ [41] and Bai [42], the common factor panel model can be summarized as presented below.

Assuming that $X_{i t}$ stands for observed data on the $i$ th cross-section object at $t$ point in time where $i=1,2, \cdots, N$ and $t=1,2, \cdots, T$, then the following model is considered.

$$
X_{i t}=\lambda_{i}^{\prime} F_{t}+e_{i t}
$$

Therein, $F_{t}, \lambda_{i}$, and $e_{i t}$ respectively stand for a vector of common factors, a vector of factor loadings related to $F_{t}$, and idiosyncratic components of $X_{i t}$. Product $\lambda_{i}^{\prime} F_{t}$ is called the common component of $X_{i t}$. Equation (2) is designated as the factor representation of $X_{i t}$. The factors, factor loadings, and idiosyncratic components are unobservable.

For an earlier study, [40] used regression residuals method, by which savings and investment rates are regressed on a set of variables presumed to control the common influences that affect the regressands. In fact, [40] applied this method to regional data for Japan in addition to international cross-section datasets, simultaneously making use of variables of three groups affecting savings and investment rates: 1) growth variables (growth in productivity and labor force); 2) wealth variables such as the end-of-period per capita regional GDP; and 3) fiscal variables (local government investment and the central government transfers to the local government). The literature described derivation of residuals from these regressions, and used them to estimate the correlation coefficients between savings and investment rates and their asymptotic standard errors.

After deriving idiosyncratic components $e_{i t}$ for savings and investment rates in Equation (2), this paper presents estimation of the bootstrap Bias corrected and accelerated $(\mathrm{BCa})$ confidence intervals of the correlation coefficient, and the relative variances between the period averages of the idiosyncratic components of savings and investments rates, assuming that the period averages are iid.

The appropriate number of common factors in Equation (2) is found according to the criteria presented by Bai and $\mathrm{Ng}$ [41] and by Onatski [43]. [41] propose the following criteria.

$$
\begin{aligned}
& P C_{p 1}(k)=V\left(k, \hat{F}^{k}\right)+k \hat{\sigma}^{2}\left(\frac{N+T}{N T}\right) \ln \left(\frac{N T}{N+T}\right) \\
& P C_{p 2}(k)=V\left(k, \hat{F}^{k}\right)+k \hat{\sigma}^{2}\left(\frac{N+T}{N T}\right) \ln C_{N T}^{2} \\
& P C_{p 3}(k)=V\left(k, \hat{F}^{k}\right)+k \hat{\sigma}^{2}\left(\frac{\ln C_{N T}^{2}}{C_{N T}^{2}}\right) \ln C_{N T}^{2}
\end{aligned}
$$




$$
\begin{aligned}
& I C_{p 1}(k)=\ln \left(V\left(k, \hat{F}^{k}\right)\right)+k\left(\frac{N+T}{N T}\right) \ln \left(\frac{N T}{N+T}\right) \\
& I C_{p 2}(k)=\ln \left(V\left(k, \hat{F}^{k}\right)\right)+k\left(\frac{N+T}{N T}\right) \ln C_{N T}^{2} \\
& I C_{p 3}(k)=\ln \left(V\left(k, \hat{F}^{k}\right)\right)+k\left(\frac{\ln C_{N T}^{2}}{C_{N T}^{2}}\right)
\end{aligned}
$$

and

$$
B I C_{3}(k)=V\left(k, \hat{F}^{k}\right)+k \hat{\sigma}^{2}\left(\frac{(N+T-k) \ln (N T)}{N T}\right)
$$

The values of $k$ that minimize these criteria determine the appropriate number of common factors. They are denoted respectively as $P C_{P 1}, P C_{P 2}, P C_{P 3}$, $I C_{P 1}, I C_{P 2}$, and $I C_{P 3}$, and $B I C_{3}$ in the table objects of footnotes 13 and 14 in addition to Table 1 and Table 2 . The empirical studies below uniformly hold that $1 \leq k \leq 10$.

Onatski's criterion for determining the number of common factors is presented below.

Assuming that the eigenvalues of the sample covariance matrix are $\lambda_{1}, \lambda_{2}, \lambda_{3}, \cdots$ in descending order, then given a threshold value $\delta$, the following $\hat{\gamma}(\delta)$ gives a consistent estimator for the number of common factors:

$$
\hat{\gamma}(\delta)=\max \left\{i \leq \gamma_{\max }^{n}: \lambda_{i}-\lambda_{i+1} \geq \delta\right\} .
$$

In this procedure, points $i$ where the difference of consecutive eigenvalues exceeds $\delta$ are identified first. One then selects the largest $i$ that is yet smaller than or equal to pre-specified $\gamma_{\max }^{n}$, which we set to 10 . To implement this procedure, one must ascertain the value of $\delta$. [43] describes a method to calculate $\delta$.

\subsection{Tests of Panel Data}

For modelling cross-section dependence in the panel unit root and cointegration tests, Bai and $\mathrm{Ng}$ [12], Bai and Kao [18], and Gengenbach et al. [44] make use of the factor structure ${ }^{11}$ in which the idiosyncratic components are assumed to be cross-sectionally independent. For example, "The second is a consequence of the fact that the idiosyncratic components in a factor model can only be weakly correlated across $i$ by design. In contrast, $X_{i t}$ will be strongly correlated across units if the data obey a factor structure. Consequently, pooled tests based upon $e_{i t}$ are more likely to satisfy the cross-section independence assumption required for pooling" (p. 1128, Bai and $\mathrm{Ng}$ [12]), where $X_{i t}, i$ and $e_{i t}$ respectively stand for the series having a factor structure, the $i$ th cross-section unit, and the idiosyncratic component. As described herein, "the first generation" ([17]) panel unit root and cointegration test methods that do not incorporate the ${ }^{11}$ [17] refers to the following factors that give rise to the cross-section dependence, such as omitted observed common factors, spatial spillover effects, social interactions, unobserved common factors, and general residual interdependence, which might remain even when all the observed and unobserved common effects are considered. 
cross-sectional dependence are used because only the idiosyncratic components of investment and savings rates are analyzed for testing the F-H puzzle under the premise that the common factors have nothing to do with mobility of international capital flows.

\subsubsection{Panel Unit Root Test}

In Tables 3-10, the following abbreviations are used for the names of panel unit root tests. LLC, IPS, MW-ADF, MW-PP, and Hadri respectively stand for tests reported by Levin, Lin and Chu [45], Im, Pesaran, and Shin [46], Maddala-Wu ADF tests(Maddala and $\mathrm{Wu}[47])$, Maddala-Wu Phillips-Perron tests ([47]), and Hadri Z-stat tests(Hadri [48]).

LLC is an ADF type of test for the null hypothesis of common integrated time series among all cross-section units. This test assumes common autoregressive coefficients for both the null and the alternative hypotheses. The alternative hypothesis of this test means that all cross-section units are stationary.

IPS is an ADF type of test that admits differences in autoregressive coefficients among cross-section units. Rejection of the null hypothesis of a unit root for all individual units means that some (including a single) cross-section unit(s) do(es) not have a unit root.

Maddala-Wu (ADF) (MW-ADF, hereinafter) and Maddala-Wu (Phillips-Perron) (MW-PP, hereinafter) share the same null and the alternative hypotheses with the IPS test, but allow unbalanced panel data and different lag lengths. They make use of $p$ values from the ADF and PP types of tests to derive the chi-square test statistic.

Hadri (Z-stat tests) [48] (Hadri, hereinafter) presents a residual-based LM test in which the null is no unit root around a deterministic level or trend for all cross-section units, against the alternative of nonstationarity for all cross-section units.

\subsubsection{Panel Cointegration Tests}

Pedroni ([14] [49]) tests the null hypothesis of unit root in the residual autoregressive equation for the cointegration equation between the two variables. The alternatives are either a common autoregressive coefficient that is less than one, or different autoregressive coefficients that are less than one across the cross-section units.

Kao [50] tests the null hypothesis of no cointegration for all cross-section units against the alternative of the different ADF coefficient across cross-section units. The test statistic is asymptotic standard normally distributed.

Maddala-Wu (MW; [47]) tests are a Johansen-Fisher type of cointegration test. The results of the trace $\left(\lambda_{\text {trace }}\right)$ and the maximum eigenvalue $\left(\lambda_{\max }\right)$ tests are presented. The nulls of the tests are that the number of cointegrated relations is either none or at most one.

\subsection{Confidence Interval}

Idiosyncratic components of investment and savings rates are averaged over 
time to form single cross-section data. Assuming that these period averages are iid over the cross-sectional units, bootstrap BCa confidence intervals (Efron [51] [52], Efron and Tibshirani [53] [54], Good [55], Manly [56]) of the correlation coefficient and the relative variances of investment and savings rates are constructed. The confidence intervals of the correlation coefficient are consistent with mobile capital flows across international and intranational borders when the intervals include the value of zero in the region. This criterion was applied to analyses of regional Philippines data reported by [26]. The variance ratio, however, would take greater values in cases for which the capital flows are mobile than in cases of immobile capital flows. This outcome is presumed to occur because the mobility of capital transfers particularly addresses sources of domestic investment funds, either foreign or domestic. Therefore, when capital mobility is high, domestic investment is likely to fluctuate with greater magnitude than domestic savings.

\section{Data}

Investment and savings rates are defined as a proportion of GDP. Data sources for OECD countries were OECD ([57] [58]). National Accounts of OECD Countries, Volume 1: Main Aggregates, 1960-1996, 1997-2014, OECD Publishing, OECD [59]), National Accounts of OECD Countries, Volume 2015 Issue 1: Main Aggregates, 2007-2014, OECD Publishing, and OECD [60], National Accounts of OECD Countries, Volume 2017 Issue 1: Main Aggregates, 2008-2015, OECD Publishing.

The following computations of OECD data use the concept of gross savings. As described herein, the gross savings are defined by adding consumption of fixed capital to net savings in the following relation:

Net savings $=$ Gross capital formation - Consumption of fixed capital

+ Net lending + Acquisition less disposal of non-financial non-produced assets - Net capital transfers from the rest of the world.

Earlier studies such as those reported by [6] [9], and [19] demonstrated that the empirical validity of the F-H puzzle was negatively influenced by establishment of the European Union (EU) (1993) and the Euro zone (1999). The OECD dataset was divided into period I of 1968-1996 and period II of 1997-2015 to reflect the two distinctly different regimes. Formation of the common currency zone has been more important than the EU for existence of the puzzle in the sense that exchange rate risks were removed. As another consideration, public announcements of the institutional changes made one or two years before 1999 induced investors, entrepreneurs, and households to behave as if the system had already been established.

The panel data of period I and II respectively comprise data of 24 and 29 OECD countries. When 24 out of 36 current OECD countries are included in the OECD dataset for period I, the member countries are Australia, Austria, Belgium, Canada, Denmark, Finland, France, Greece, Iceland, Ireland, Italy, Japan, 
Luxembourg, Netherlands, New Zealand, Norway, Portugal, Spain, Sweden, Switzerland, Turkey, the United Kingdom, the United States, and Mexico. When 29 countries are included in the OECD dataset for period II, the member countries above are included with the additional six countries of Czech Republic, Germany, Hungary, Korea, Poland, and Slovak Republic to the 24 members named above, with Turkey deleted.

No report describes a study of regional data analyses in the framework of the panel unit root and cointegration methods for examining the F-H puzzle. This paper presents analysis of a panel of the regional data of Japan and Indonesia.

The sources of Japanese prefectural data were the Annual Report on Prefectural Accounts on the Cabinet Office on the website of the Government of Japan. Private and gross investment is included along with total (public plus private) savings in the Japanese regional data. Decomposition of aggregate investment into public and private investments in 1998 and 1999 for Ibaraki Prefecture was not available. For Japan, private investment uses panel data for 1975-1997, with $N=47$ and $T=23$.

The Japanese prefectural data are available for subsequent observation periods of 1990-2003, 1996-2009, and 2001-2014. The entire prefectural System of National Accounts (SNA) for these periods is based on the 1993 SNA criterion. Regional data for the 1975-1997 period, however, were constructed on the 1968 SNA criterion. In addition to differences in the basic SNA standard, changes in specific criteria applied to fundamental data construction methods across these observation periods make the expansion of the observation period from 1975-1997 to a more recent time period inapplicable ${ }^{12}$.

The 47 Japanese prefectures analyzed are the following: Hokkaido, Aomori, Akita, Iwate, Fukushima, Miyagi, Niigata, Yamagata, Toyama, Ishikawa, Fukui, Ibaraki, Tochigi, Gunma, Yamanashi, Nagano, Chiba, Tokyo, Saitama, Kanagawa, Shizuoka, Gifu, Shiga, Mie, Aichi, Nara, Wakayama, Osaka, Kyoto, Hyogo, Okayama, Tottori, Shimane, Hiroshima, Yamaguchi, Kagawa, Ehime, Tokushima, Kochi, Fukuoka, Saga, Nagasaki, Oita, Miyazaki, Kumamoto, Kagoshima, and Okinawa.

The source of Indonesian regional data is the Gross Regional Domestic Product of Provinces in Indonesia by Expenditure (Badan Pusat Statistik [61], Jakarta-Indonesia, Government of Indonesia). The analyses described in this paper use panel data of Indonesia for 1983-2012, with $N=26$ and $T=30$. Only aggregate and gross savings and investment data are available for the 26 Indonesian provinces, which are Dista. Aceh, Sumatra Utara, Sumatra Barat, Riau, Jambi, Sumatra Selatan, Bengkulu, Lampung, DKI Jakarta, Jawa Barat, Jawa Tengah, Dista. Yogyakarta, Jawa Timur, Bali, Kalimantan Barat, Kalimantan Tengah, Kalimantan Selatan, Kalimantan Timur, Sulawesi Utara, Sulawesi Tengah, Sulawesi Selatan, Sulawesi Tenggara, Nusa Tenggara Barat, Nusa Tenggara Timur, Malu$\mathrm{ku}$, and Irian Jaya.

${ }^{12}$ Panel data of Japanese regions for 2001-2014 were analyzed by [26]. The parameter estimates, however, were adversely affected by small sample biases. 


\section{Estimation Results}

\subsection{Estimates of the Number of Common Factors}

The appropriate numbers of common factors in Equation (2) were calculated for OECD countries, Japan, and Indonesia. The results are presented in Table 1 and Table 2.

In Table 1 and Table 2, criteria for the appropriate numbers of common factors correspond to Equations (4) and (5) for the Bai and $\mathrm{Ng}$ [41] criteria, and the Onatski [43] criterion in Section 2-1.

Table 1. Appropriate numbers of common factors.

\begin{tabular}{|c|c|c|c|}
\hline \multicolumn{4}{|c|}{ Period I of OECD countries $(1968-1996, N=24, T=29, N T=696)$} \\
\hline \multicolumn{4}{|c|}{ Numbers of factors for gross savings: } \\
\hline \multirow[t]{2}{*}{ Bai-Ng (2002) } & ICp2 & $\mathrm{BIC} 3$ & Onatski \\
\hline & 1 & 10 & 1 \\
\hline \multicolumn{4}{|c|}{ Numbers of factors for gross investment: } \\
\hline \multirow[t]{2}{*}{ Bai-Ng (2002) } & ICp2 & BIC3 & Onatski \\
\hline & 1 & 10 & 1 \\
\hline \multicolumn{4}{|c|}{ Period II of OECD countries $(1997-2015, N=29, T=19, N T=551)$} \\
\hline \multicolumn{4}{|c|}{ Numbers of factors for gross savings: } \\
\hline \multirow[t]{2}{*}{ Bai-Ng (2002) } & ICp2 & $\mathrm{BIC} 3$ & Onatski \\
\hline & 10 & 10 & 5 \\
\hline \multicolumn{4}{|c|}{ Numbers of factors for gross investment: } \\
\hline \multirow[t]{2}{*}{ Bai-Ng (2002) } & $\mathrm{ICp} 2$ & BIC3 & Onatski \\
\hline & 10 & 10 & 3 \\
\hline
\end{tabular}

Table 2. Appropriate numbers of common factors.

\begin{tabular}{|c|c|c|c|}
\hline \multicolumn{3}{|c|}{ Japan $(1975-1997, N=47, T=23, N T=1081)$} & \\
\hline \multicolumn{3}{|c|}{ Numbers of factors for total savings: } & \\
\hline \multirow[t]{2}{*}{ Bai-Ng (2002) } & ICp2 & $\mathrm{BIC} 3$ & Onatski \\
\hline & 10 & 8 & 3 \\
\hline \multicolumn{4}{|c|}{ Numbers of factors for private investment: } \\
\hline \multirow[t]{2}{*}{ Bai-Ng (2002) } & $\mathrm{ICp} 2$ & $\mathrm{BIC} 3$ & Onatski \\
\hline & 10 & 7 & 1 \\
\hline \multicolumn{4}{|c|}{ Indonesia $(1983-2012, N=26, T=30, N T=780)$} \\
\hline \multicolumn{3}{|c|}{ Numbers of factors for gross savings: } & \\
\hline \multirow[t]{2}{*}{ Bai-Ng (2002) } & ICp2 & BIC3 & Onatski \\
\hline & 9 & 9 & 10 \\
\hline \multicolumn{4}{|c|}{ Numbers of factors for gross investment: } \\
\hline \multirow[t]{2}{*}{ Bai-Ng (2002) } & $\mathrm{ICp} 2$ & BIC3 & Onatski \\
\hline & 10 & 9 & 5 \\
\hline
\end{tabular}


The numbers of common factors consistent with the criteria reported by [41] and by [43] in the tables are considerably different. They take a minimum value of one and a maximum value of ten. The idiosyncratic components of the variables to be analyzed in the present study correspond to the number of common factors presented in Table $1^{13}$ and Table $2^{14}$. For robustness purposes, however, empirical examinations are made for all cases of ten idiosyncratic components in the following estimations.

\subsection{Unit Roots}

Panel unit root tests of LLC, IPS, MW-ADF, MW-PP, and Hadri were applied to the idiosyncratic components of investment and savings rates for the two periods of OECD countries, and for regional data of Japan and Indonesia.

In Table 3 and Table 4, which report unit root test results for two variables of investment and savings rates for period I of OECD countries, the stationarity results are more visible than the nonstationarity results. The nonstationarity results derived primarily from the Hadri test, however, give rise to the possibility of running cointegrated equation estimation procedures.

The investment rate in period II of OECD countries shows nonstationarity

Table 3. Panel unit root tests: OECD Period I (1968-1996; $N=24, T=29)$.

\begin{tabular}{ccc}
\hline Gross saving & Stationary & Nonstationary \\
\hline LLC & $10^{*}$ & \\
IPS & $10^{*}$ & \\
MW-ADF & $10^{*}$ & $10^{* *}$ \\
MW-PP & $10^{*}$ & \\
Hadri & & \\
\hline
\end{tabular}

Numbers stand for the numbers of idiosyncratic components that caused stationarity or nonstationarity in rejection of the null hypothesis for $p<0.1$. Numbers sum to ten, which is the maximum number of common factors computed. The $p$ values are the following: ${ }^{*}, p<0.05$; and ${ }^{* *}, p<0.01$.

${ }^{13}$ Choi and Jeong [62] propose the practical advice of considering several criteria simultaneously based on their simulation results, which show that it is a difficult task to find a best performing criterion in finding the number of common factors. In accord with the literature, other estimates of Bai and $\mathrm{Ng}$ [41] criteria that were excluded from Table 1 are presented. For period I of OECD countries, the number of common factors is presented in parentheses as shown below.

Gross savings $\quad P C_{P 1}(10) I C_{P 1}(1) P C_{P 2}(7) P C_{P 3}(10) I C_{P 3}(10)$

Gross investment $P C_{P 1}(10) I C_{P 1}(1) P C_{P 2}(9) P C_{P 3}(10) I C_{P 3}(10)$

For period II of OECD countries the estimates are the following.

Gross savings $\quad P C_{P 1}(10) I C_{P 1}(10) P C_{P 2}(10) P C_{P 3}(10) I C_{P 3}(10)$

Gross investment $P_{C_{P 1}}(10) I C_{P 1}(10) P C_{P 2}(10) P C_{P 3}(10) I C_{P 3}(10)$

${ }^{14}$ The estimates of Bai and $\mathrm{Ng}(2002)$ criteria excluded from Table 2 are presented below. Japanese common factor estimates are in parentheses.

Total savings $\quad P C_{P 1}(10) I C_{P 1}(10) P C_{P 2}(10) P C_{P 3}(10) I C_{P 3}(10)$

Private investment $P C_{P 1}(10) I C_{P 1}(10) P C_{P 2}(10) P C_{P 3}(10) I C_{P 3}(10)$

Indonesian common factor estimates are in parentheses.

Gross savings $\quad P C_{P 1}(10) I C_{P 1}(10) P C_{P 2}(10) P C_{P 3}(10) I C_{P 3}(10)$

Gross investment $P C_{P 1}(10) I C_{P 1}(10) P C_{P 2}(10) P C_{P 3}(10) I C_{P 3}(10)$ 
Table 4. Panel unit root tests: OECD Period I (1968-1996; $N=24, T=29)$.

\begin{tabular}{ccc}
\hline Gross investment & Stationary & Nonstationary \\
\hline LLC & 10 & \\
IPS & 10 & \\
MW-ADF & 10 & 10 \\
MW-PP & 10 & \\
Hadri & & \\
\hline
\end{tabular}

Numbers stand for the numbers of idiosyncratic components that caused stationarity or nonstationarity in rejection of the null. Numbers sum to ten, which is the maximum number of common factors computed. All $p$ values are less than 0.01 .

results more often in Table 5 than in Table 4. The savings rate in Table 6, however, is likely to show stationarity more often than nonstationarity. Considering that some nonstationarity results are reported in this table, the two variables are tested for cointegration as described in the next section.

The Japanese regional savings rate shows stationarity results very often, except a single case obtained with the Hadri test presented in Table 7. Table 8 for the Japanese regional private investment rate presents similar results, in a sense, with those shown in Table 5, where all the Hadri test results indicate the nonstationarity of the variable. When examining the F-H puzzle, regional data are analyzed as the benchmark for finding no linear relation between investment and savings rates. When the two variables are interpreted as stationary variables, then there is expected to be no cointegration for the variables, thereby implying that capital flows are mobile across intranational borders. Formal cointegration tests for the two variables described in the next section provide a statistical basis for this inference.

Unit root test results for the two variables of Indonesian regions in Table 9 and Table 10 are similar to test results obtained for Japanese regional data and presented in Table 7 and Table 8 with respect to showing more visible stationarity results than nonstationarity results. Indonesian regional data of investment and savings rates are therefore tested for cointegration in the next section because nonstationarity results were obtained.

\subsection{Cointegration}

Based on the mixing results observed in the panel unit root tests, the idiosyncratic components of national and regional investment and savings rates were tested for cointegration by application of the tests of Pedroni with common and individual autoregressive (AR) coefficients, of Kao and of MW.

Table 11 shows that, in period I of OECD countries, greater numbers of idiosyncratic components show a cointegrating relation between the two variables of investment and savings rates than the number of idiosyncratic components, which presents results of no cointegration. The empirical evidence presented here is interpreted as implying that the F-H puzzle existed in this time period. 
Table 5. Panel unit root tests: OECD Period II (1997-2015; $N=29, T=19)$.

\begin{tabular}{ccc}
\hline Gross saving & Stationary & Nonstationary \\
\hline LLC & $10^{*}$ & $1^{* *}$ \\
IPS & $9^{*}$ & \\
MW-ADF & $10^{*}$ & \\
MW-PP & $10^{*}$ & $2^{* * * *}$ \\
Hadri & $8^{* * *}$ &
\end{tabular}

Numbers stand for the numbers of idiosyncratic components that caused stationarity or nonstationarity in rejection of the null hypothesis for $p<0.1$, and not in rejection of the null hypothesis otherwise. Numbers sum to ten, the maximum number of common factors computed. The $p$ values are the following: ${ }^{*}, p<0.01$; ${ }^{* *}$, one case corresponds to the number of common factors equal to 10 with $p=0.099$; ${ }^{* *}, p>0.5$; and ${ }^{* * * *}$, two cases correspond to the number of common factors equal to 1 and 10 with $p=0.0000$.

Table 6. Panel unit root tests: OECD Period II (1997-2015; $N=29, T=19)$.

\begin{tabular}{ccc}
\hline Gross investment & & \\
\hline LLC & Stationary & Nonstationary \\
IPS & $5^{*}$ & $5^{*}$ \\
MW-ADF & $6^{* * *}$ \\
MW-PP & $8^{*}$ & $4^{* * * *}$ \\
Hadri & & $2^{* * * *}$ \\
\hline
\end{tabular}

Numbers stand for the numbers of idiosyncratic components that caused stationarity or nonstationarity in rejection of the null hypothesis for $p<0.1$, and not in rejection of the null hypothesis otherwise. Numbers sum to ten, the maximum number of common factors computed. The $p$ values are the following: ${ }^{*}, p<0.1$; ${ }^{* *}, p>0.1{ }^{* * *}, p>0.2 ;^{* * *}, p>0.1{ }^{* * * * *}$, two cases correspond to the number of common factors equal to 9 and 10 with $p>0.1$, and $p=0.0000 ;{ }^{* * * * *}, p<0.01$.

Table 7. Panel unit root tests: Japan (1975-1999; $N=47, T=25)$.

\begin{tabular}{ccc}
\hline Total saving & & \\
\hline LLC & Stationary & Nonstationary \\
IPS & $10^{*}$ & \\
MW-ADF & $10^{*}$ & \\
MW-PP & $10^{*}$ & $11^{* * *}$ \\
Hadri & $10^{*}$ & \\
\hline
\end{tabular}

Numbers stand for the numbers of idiosyncratic components that caused stationarity or nonstationarity in rejection of the null. Numbers sum to ten, the maximum number of common factors computed. The $p$ values are the following: ${ }^{*}, p=0.0000{ }^{* *}, p>0.7$, and ${ }^{* * *}$, one case corresponds to the number of common factors equal to 10 with $p=0.0000$.

Table 8. Panel unit root tests: Japan (1975-1999; $N=47, T=25)$.

\begin{tabular}{ccc}
\hline Private investment & & \\
\hline & Stationary & Nonstationary \\
\hline LLC & 10 & \\
IPS & 10 & \\
\hline
\end{tabular}




\section{Continued}

\begin{tabular}{ccc}
\hline MW-ADF & 10 & \\
MW-PP & 10 & 10 \\
Hadri & & \\
\hline
\end{tabular}

Numbers stand for the numbers of idiosyncratic components that caused stationarity or nonstationarity in rejection of the null hypothesis for $p<0.1$. Numbers sum to ten, the maximum number of common factors computed. The $p$ value applied to the test results in this table was 0.0000 .

Table 9. Panel unit root tests: Indonesia $(1983-2012 ; N=26, T=30)$.

\begin{tabular}{ccc}
\hline Total gross saving & & \\
\hline & Stationary & Nonstationary \\
\hline LLC & $10^{\star}$ & \\
IPS & $10^{\star}$ & \\
MW-ADF & $10^{\star}$ & \\
MW-PP & $10^{\star}$ & $2^{* * * *}$ \\
Hadri & $8^{* * *}$ & \\
\hline
\end{tabular}

Numbers stand for the numbers of idiosyncratic components that caused stationarity or nonstationarity in rejection of the null hypothesis for $p<0.1$, and not in rejection of the null hypothesis otherwise. Numbers sum to ten, the maximum number of common factors computed. The $p$ values are the following: ${ }^{*} p<0.01$; ${ }^{* *} p<0.1 ;{ }^{* * *} p>0.3$, and ${ }^{* * * *}$, two cases correspond to the number of common factors equal to 2 with $p=$ 0.0883 , and the number of common factors equal to 10 with $p=0.0000$.

Table 10. Panel unit root tests: Indonesia (1983-2012; $N=26, T=30)$.

\begin{tabular}{ccc}
\hline Total gross investment & Stationary & Nonstationary \\
\hline LLC & $10^{*}$ & \\
IPS & $10^{* *}$ & \\
MW-ADF & $10^{* * *}$ & \\
MW-PP & $10^{* *}$ & $10^{* * *}$ \\
Hadri & & \\
\hline
\end{tabular}

Numbers stand for the numbers of idiosyncratic components that caused stationarity or nonstationarity in rejection of the null hypothesis for $p<0.1$. Numbers sum to ten, the maximum number of common factors computed. The $p$ values are the following: ${ }^{*}, p<0.01$; $^{* *}, p<0.05 ;{ }^{* * *}, p<0.1$; ${ }^{* * *}, p=0.0000$.

Table 11. Panel cointegration tests: OECD Priod I (1968-1996; $N=24, T=29)$.

\begin{tabular}{ccc}
\hline & No cointegration & Cointegration \\
\hline Pedroni & & \\
Common AR coeffs. & & $10^{*}$ \\
Individual AR coeffs. & $2^{* * *}$ & $10^{* *}$ \\
Cao & $3^{* * * * *}$ & $8^{* * *}$ \\
MW & $7^{* * * * *}$ \\
\hline
\end{tabular}

Numbers stand for the numbers of idiosyncratic components that caused no cointegration or cointegration in rejection of the null hypothesis for $p<0.1$, and not in rejection of the null hypothesis for $p>0.1$. Numbers sum to ten, the maximum number of common factors computed. The null hypothesis of MW test is that the number of cointegrated relation is either none or at most one. The $p$ values are the following: ${ }^{*}, p<$ 0.05 ; $^{* *}, p<0.01$. $^{* *}$, two cases correspond to the number of common factors equal to 1 with $p=0.267$, and the number of common factors equal to 2 with $p=0.3865$; ${ }^{* * *}, p<0.05$; ${ }^{* * * *}$, three cases correspond to the number of common factors equal to 4 with $p=0.0811$, the number of common factors equal to 5 with $p$ $=0.09129$, and the number of common factors equal to 7 with $p=0.0608$; ${ }^{* * * * *}, p>0.1$. 
Results of panel cointegration analyses of the idiosyncratic components of the two variables for period II of OECD countries in Table 12, however, are likely to indicate that the puzzle has ceased to exist. This inference is reinforced by the results presented in Table 13 and Table 14, which show regional data of Japan and Indonesia tested for panel cointegration under the premise that intranational capital flows are mobile within a single country.

Table 13 and Table 14 present results of cointegration tests conducted of Japanese and Indonesian regional data. No cointegration results are more readily apparent than cointegration results in the tables, suggesting that intranational capital flows are mobile in both countries.

The analytical framework of the existing literature, such as reports presented by Byrne et al. [11], Costantini and Gutierez [16], and Drakos, Kouretas, and Vlamis [23] differs from that presented herein. Without partitioning, the entire sample period of the panel data, common factors, and idiosyncratic components of the investment and savings rates of OECD countries were tested for panel unit root, and were found to be I(1) by [11] and by [23]. In fact, cointegration among

Table 12. Panel cointegration tests: OECD Period II $(1997-2015 ; N=29, T=19)$.

\begin{tabular}{ccc}
\hline & No cointegration & Cointegration \\
\hline Pedroni & $10^{*}$ & \\
Common AR coeffs. & $10^{\star}$ & \\
Individual AR coeffs. & $6^{*}$ & $4^{* *}$ \\
Cao & $10^{* * *}$ & \\
MW & & \\
\hline
\end{tabular}

Numbers stand for the numbers of idiosyncratic components that caused no cointegration or cointegration in rejection of the null hypothesis for $p<0.1$, and not in rejection of the null hypothesis for $p>0.1$. Numbers sum to ten, the maximum number of common factors computed. The null hypothesis of MW test is that the number of cointegrated relation is either none or at most one. The $p$ values are the following: ${ }^{*}, p>$ 0.1 ; ${ }^{* *}$, four cases correspond to the number of common factors equal to 4 with $p=0.0984$, the number of common factors equal to 8 with $p=0.0709$, the number of common factors equal to 9 with $p=0.0002$, and the number of common factors equal to 10 with $p=0.0000$; ${ }^{* *}, p<0.05$.

Table 13. Panel cointegration tests: Japan (1975-1999; $N=47, T=25)$.

\begin{tabular}{ccc}
\hline & No cointegration & Cointegration \\
\hline Pedroni & $9^{*}$ & $1^{* *}$ \\
Common AR coeffs. & $9^{*}$ & $1^{* *}$ \\
Individual AR coeffs. & $2^{* * *}$ & $8^{* * *}$ \\
Kao & $10^{* * *}$ & \\
MW &
\end{tabular}

Numbers stand for the numbers of idiosyncratic components that caused no cointegration or cointegration in rejection of the null hypothesis for $p<0.1$, and not in rejection of the null hypothesis for $p>0.1$. Numbers sum to ten, the maximum number of common factors computed. The null hypothesis of MW test is that the number of cointegrated relation is either none or at most one. The $p$ values are the following: ${ }^{*}, p>$ 0.9 ; $* *$, cases of one cointegrated relation correspond to the number of common factors equal to 3 with $p<$ 0.01 ; $* * *$, two cases correspond to the number of common factors equal to 9 with $p=0.2638$, and the number of common factors equal to 10 with $p=0.3762$; ${ }^{* * *} p<0.05$. 
Table 14. Panel cointegration tests: Indonesia (1983-2012; $N=25, T=30)$.

\begin{tabular}{ccc}
\hline & No cointegration & Cointegration \\
\hline Pedroni & $10^{*}$ & \\
Common AR coeffs. & $10^{*}$ & \\
Individual AR coeffs. & & $10^{* *}$ \\
Cao & $6^{*}$ & $4^{* * * *}$ \\
MW & & \\
\hline
\end{tabular}

Numbers stand for the numbers of idiosyncratic components that caused no cointegration or cointegration in rejection of the null hypothesis for $p<0.1$, and not in rejection of the null hypothesis for $p>0.1$. Numbers sum to ten, the maximum number of common factors computed. The null hypothesis of MW test is that the number of cointegrated relation is either none or at most one. The $p$ values are the following: ${ }^{*}, p>$ $0.3 ;^{* *}, p<0.05 ;{ }^{* *}, p<0.1 ;{ }^{* * *}$, four cases correspond to the number of common factors equal to 6 with $p$ $=0.2836$, the number of common factors equal to 7 with $p=0.1126$, the number of common factors equal to 8 with $p=0.5692$ and the number of common factors equal to 10 with $p=0.1331$.

common factors was identified as the source of the F-H puzzle because of the empirical results indicating that idiosyncratic components of the two variables are not cointegrated in panel cointegration methodologies. As reported by [16], by contrast, panel unit root tests showed the results that common factors and idiosyncratic components were, respectively, I(1), and I(0) variables. Significant cointegrated relations, as evidence of the $\mathrm{F}-\mathrm{H}$ puzzle, were estimated between common factors of the two variables, but the estimated savings coefficient was very close in magnitude to zero. From such empirical findings, the literature derived a negative interpretation about the existence of the F-H puzzle.

This paper presents the interpretation that the economic meaning of the two variables' common factors is that of implying global factors of cyclical and financial fluctuations ([10] [40]) along with the influences of other variables described explicitly in the Methods section. There, various statistical methods were described as attempts to tackle the simultaneity problem caused by the common influences on the two variables. In accordance with these statistical frameworks designed to examine the specific sources of the puzzle, this paper analyzed only idiosyncratic components of investment and savings rates. The epoch-making events of the European Union and the euro zone formation made it possible to divide the observation period into two parts at around the time of these events to obtain results that are consistent with the attenuating savings coefficient estimates over time, which have been reported in the literature ([6] [9] [10] [15] [19] [26]).

\section{BCa Confidence Intervals}

Period averages of idiosyncratic components of investment and savings rates are used to compute the correlation coefficient and the variance ratio of the two variables. Corresponding to the benchmark value of the F-H savings coefficient for mobile capital flows, the necessary and sufficient condition for international and intranational capital flows to be mobile in these analyses is that the confidence 
intervals of the correlation coefficient include the value of zero in the region. To ascertain if any economically meaningful relation exists between capital mobility and the relative variances of the two variables, the confidence intervals of the variance ratio are also constructed.

\subsection{Correlation: OECD Countries}

The upper panel of Table 15 presents the 95\% confidence intervals of the correlation coefficient between the gross savings and investments rates for period I of OECD countries ${ }^{15}$. The hypothesis that international capital flows are mobile can be rejected no matter how many common factors are considered, as this table shows.

Table 15. 95\% BCa confidence interval of Correlation coefficient.

\begin{tabular}{|c|c|c|c|c|}
\hline \multicolumn{5}{|c|}{ OECD (Gross savings, 1968-1996. $N=24, T=29, N T=696$ ) } \\
\hline No. of Factors & Confidence interval & $\hat{a}$ & $\hat{z}_{0}$ & Sample estimate \\
\hline 1 & $(0.487674,0.836918)$ & 0.0223135 & -0.190820 & 0.735557 \\
\hline 2 & $(0.497660,0.855701)$ & -0.023135 & -0.197632 & 0.764558 \\
\hline 3 & $(0.524156,0.867715)$ & -0.054166 & -0.210428 & 0.793041 \\
\hline 4 & $(0.649917,0.889942)$ & -0.014458 & -0.243868 & 0.825500 \\
\hline 5 & $(0.813059,0.947233)$ & -0.013709 & -0.209574 & 0.912026 \\
\hline 6 & $(0.802923,0.958991)$ & -0.021348 & -0.145900 & 0.915744 \\
\hline 7 & $(0.870519,0.971347)$ & 0.007386 & -0.198484 & 0.943478 \\
\hline 8 & $(0.919439,0.984931)$ & 0.002718 & -0.132402 & 0.966385 \\
\hline 9 & $(0.995651,0.999111)$ & 0.051234 & -0.130716 & 0.997990 \\
\hline 10 & $(0.999562,0.999917)$ & 0.085339 & -0.001671 & 0.999787 \\
\hline \multicolumn{5}{|c|}{ OECD (Gross savings, 1997-2015. $N=29, T=19, N T=551$ ) } \\
\hline No. of Factors & Confidence interval & $\hat{a}$ & $\hat{z}_{0}$ & Sample estimate \\
\hline 1 & $(-0.259412,0.458893)$ & -0.017424 & -0.009191 & 0.101994 \\
\hline 2 & $(-0.306010,0.300288)$ & 0.019612 & -0.007520 & -0.027297 \\
\hline 3 & $(-0.091515,0.415701)$ & $-7.13 \times 10^{-5}$ & -0.037608 & 0.169423 \\
\hline 4 & $(-0.111353,0.444279)$ & 0.036939 & 0.011698 & 0.138652 \\
\hline 5 & $(-0.255661,0.413717)$ & 0.050647 & 0.088684 & -0.013639 \\
\hline 6 & $(-0.191098,0.268788)$ & 0.002828 & 0.06773 & 0.71018 \\
\hline 7 & $(-0.163225,0.327422)$ & 0.022533 & 0.024233 & 0.091152 \\
\hline 8 & $(-0.546867,0.189548)$ & -0.021184 & 0.021726 & -0.204631 \\
\hline 9 & $(-0.557895,0.185754)$ & -0.027370 & 0.036772 & -0.213753 \\
\hline 10 & $(-0.719348,-0.154828)$ & -0.069142 & 0.0000 & -0.459650 \\
\hline
\end{tabular}

Sample estimate represents the correlation coefficient in the sample. $\hat{a}$ and $\hat{z}_{0}$ respectively represent the acceleration constant and bias correction constant. The number of resamplings is 3000 .

${ }^{15}$ The confidence intervals presented in the upper panel of Table 15 are fundamentally identical with those presented in [26] in an attempt to reconcile the different estimation results in the literature reported by Greenway-Mcgrevy, Han, and Sul [63]. A new round of bootstrap resampling was applied for the present study to derive the results presented in the upper panel of Table 15, in which the estimates of $\hat{a}$ turned out to be the same as before. 
The lower panel of Table 15 shows $95 \%$ confidence intervals that are adopted when using the data in period II of OECD countries. For any number of common factors to be appropriate, the hypothesis of mobile capital flows is accepted using the gross savings and investment rates, as the table shows. Results in the lower panel of Table 15 indicate that the Feldstein-Horioka puzzle of international capital mobility that was established empirically for 1968-1996 in the upper panel Table 15 can no longer be demonstrated for 1997-2015, which covers the euro zone era.

The confidence interval estimation in the lower panel of Table 15 is consistent with regression estimation results reported by [10]. Using gross savings and investment rates, the common factors were included on the right-hand-side of the Feldstein-Horioka Equation (1) (“a factor augmented panel regression”), indicating that the puzzle disappears in the periods after the $1980 \mathrm{~s}^{16}$.

\subsection{Correlation: Japan}

The degree of intranational capital mobility has been tested empirically through estimation of Equation (1) in the history of the Feldstein-Horioka puzzle literature. This line of empirical examinations had the aim of exemplifying the effectiveness of estimating Equation (1) to measure the magnitude of capital mobility. Capital flows across regions of economically developed countries have been demonstrated as mobile in the literature ([28] [29] [30] [31] [32]). This empirical evidence verifies the propriety of the Feldstein-Horioka method as an indicator of the mobility of international capital flows. Regional data of economically developing countries (Indonesia and the Philippines) have been analyzed by [26] through application of the interactive fixed effects common factor panel regression methodology of MW [27]. Results presented in the upper panel of Table 16 are consistent with the hypothesis of intranational capital mobility if the number of common factors to be considered is 1 - 7. The Bai and $\mathrm{Ng}$ [41] criteria yield greater numbers for appropriate common factors than these cases in Table 2 except $\mathrm{BIC}_{3}$ for private investment, but the Onatski [43] criterion gives the appropriate number of common factors consistent with these cases. The empirical evidence presented in the upper panel of Table 16 can therefore be interpreted as implying that a lack of statistical significance of the linear relation between savings and investment rates for Japanese regional data can be the measure of mobile capital flows across intranational borders.

\subsection{Correlation: Indonesia}

Results presented in the lower panel of Table 16 are consistent with those reported by [26], showing that the hypothesis of mobile intranational capital flows holds for any number (up to 10) of common factors.

\footnotetext{
${ }^{16}$ The statistical significance of the retention coefficient in this report fades away in the periods after the 1990s, when the average G7 interest rate was used as a proxy for the common factors as the global factors to affect both investment and savings rates.
} 
Table 16. 95\% BCa Confidence interval of correlation coefficient.

\begin{tabular}{|c|c|c|c|c|}
\hline \multicolumn{5}{|c|}{ Japan (Private investment, 1975-1997. $N=47, T=23, N T=1081$ ) } \\
\hline No. of Factors & Confidence interval & $\hat{a}$ & $\hat{z}_{0}$ & Sample estimate \\
\hline 1 & $(-0.141446,0.336313)$ & -0.023547 & -0.005013 & 0.114517 \\
\hline 2 & $(-0.185052,0.361058)$ & 0.019092 & 0.025069 & 0.083116 \\
\hline 3 & $(-0.162461,0.313941)$ & 0.017500 & 0.004178 & 0.071732 \\
\hline 4 & $(-0.122346,0.366318)$ & -0.015804 & -0.073594 & 0.140775 \\
\hline 5 & $(-0.118937,0.383700)$ & -0.008338 & -0.025069 & 0.14238 \\
\hline 6 & $(-0.078905,0.469200)$ & -0.021916 & -0.032592 & 0.216601 \\
\hline 7 & $(-0.185010,0.402528)$ & 0.009002 & 0.018383 & 0.112646 \\
\hline 8 & $(0.136876,0.590075)$ & 0.032053 & 0.000000 & 0.381697 \\
\hline 9 & $(0.109223,0.577938)$ & 0.044373 & -0.050154 & 0.355468 \\
\hline 10 & $(0.191129,0.576916)$ & -0.010742 & -0.025905 & 0.396652 \\
\hline \multicolumn{5}{|c|}{ Indonesia (Aggregate investment, 1983-2012. $N=26, T=30, N T=780$ ) } \\
\hline No. of Factors & Confidence interval & $\hat{a}$ & $\hat{z}_{0}$ & Sample estimate \\
\hline 1 & $(-0.338103,0.475982)$ & -0.021159 & -0.040953 & 0.130685 \\
\hline 2 & $(-0.421559,0.472251)$ & -0.023800 & -0.068568 & 0.108654 \\
\hline 3 & $(-0.434402,0.303119)$ & -0.008079 & 0.042626 & -0.061103 \\
\hline 4 & $(-0.512118,0.217822)$ & -0.014210 & 0.018383 & -0.145471 \\
\hline 5 & $(-0.570929,0.098140)$ & -0.048794 & 0.086167 & -0.264040 \\
\hline 6 & $(-0.600980,-0.013395)$ & 0.004209 & 0.020054 & -0.372322 \\
\hline 7 & $(-0.554439,0.198259)$ & 0.033373 & 0.138304 & -0.303496 \\
\hline 8 & $(-0.589104,0.214890)$ & 0.038822 & 0.096236 & -0.307349 \\
\hline 9 & $(-0.191507,0.645720)$ & 0.013215 & -0.020890 & 0.299075 \\
\hline 10 & $(-0.508657,0.119894)$ & 0.060606 & 0.17977 & -0.247082 \\
\hline
\end{tabular}

Sample estimate represents the correlation coefficient in the sample. $\hat{a}$ and $\hat{z}_{0}$ respectively represent the acceleration constant and bias correction constant. The number of resamplings is 3000 .

\subsection{Relative Volatility: OECD Countries}

The relative volatility of investments and savings rates is defined as the ratio of the variance of the investment rate to the variance of the savings rate. The upper panel of Table 17 shows the $95 \%$ confidence intervals of the relative volatility of the gross investment and savings rates for period I of OECD countries. For a number of common factors less than eight, both limits of the intervals are located in the area greater than one. The appropriate numbers of common factors in terms of Bai and $\mathrm{Ng}$ [41] criteria often exceed this number. The Onatski [43] criterion, however, presents one common factor as appropriate for both investment and savings rates.

Another observation is illustrative. Comparison of this table with the upper panel of Table 15 elucidates that the combinations of the gross savings and 
Table 17. 95\% BCa Confidence interval of variance ratio.

\begin{tabular}{|c|c|c|c|c|}
\hline \multicolumn{5}{|c|}{ OECD (Gross savings, 1968-1996. $N=24, T=29, N T=696$ ) } \\
\hline No. of Factors & Confidence interval & $\hat{a}$ & $\hat{z}_{0}$ & Sample estimate \\
\hline 1 & $(2.081594,10.27890)$ & -0.006873 & 0.071081 & 4.974677 \\
\hline 2 & $(1.638099,7.703148)$ & -0.008299 & -0.003342 & 3.880169 \\
\hline 3 & $(1.394734,6.145656)$ & -0.001905 & 0.000000 & 3.091902 \\
\hline 4 & $(1.241679,4.535246)$ & 0.007250 & 0.010862 & 2.398888 \\
\hline 5 & $(1.169084,3.140490)$ & -0.020911 & -0.015040 & 1.948178 \\
\hline 6 & $(1.119221,2.709843)$ & -0.010070 & 0.020890 & 1.678469 \\
\hline 7 & $(1.007950,2.217862)$ & -0.006747 & 0.037608 & 1.424647 \\
\hline 8 & $(0.939955,1.613086)$ & 0.000393 & 0.019219 & 1.182025 \\
\hline 9 & $(0.989175,1.133596)$ & 0.049669 & 0.032592 & 1.038391 \\
\hline 10 & $(0.978285,1.015768)$ & 0.004175 & 0.04848 & 0.999687 \\
\hline \multicolumn{5}{|c|}{ OECD (Gross savings, 1997-2015. $N=29, T=19, N T=551$ ) } \\
\hline No. of Factors & Confidence interval & $\hat{a}$ & $\hat{z}_{0}$ & Sample estimate \\
\hline 1 & $\left(7.608795 \times 10^{6}, 6.0377075 \times 10^{7}\right)$ & 0.078859 & 0.057684 & $2.0034572 \times 10^{7}$ \\
\hline 2 & $\left(3.797731 \times 10^{6}, 3.0247282 \times 10^{7}\right)$ & 0.092630 & 0.037608 & $1.0315223 \times 10^{7}$ \\
\hline 3 & $\left(2.481613 \times 10^{6}, 2.2272173 \times 10^{7}\right)$ & 0.057542 & 0.032592 & $7.288879 \times 10^{6}$ \\
\hline 4 & $\left(2.567306 \times 10^{6}, 2.2419446 \times 10^{7}\right)$ & 0.078350 & 0.039281 & $7.242831 \times 10^{6}$ \\
\hline 5 & $\left(6.624862 \times 10^{5}, 6.137134 \times 10^{6}\right)$ & 0.069541 & 0.056011 & $1.832864 \times 10^{6}$ \\
\hline 6 & $\left(2.567277 \times 10^{5}, 2.386353 \times 10^{6}\right)$ & 0.066892 & 0.074432 & $7.258172 \times 10^{5}$ \\
\hline 7 & $\left(2.41737 \times 10^{5}, 2.112010 \times 10^{6}\right)$ & 0.063245 & 0.081975 & $6.956297 \times 10^{5}$ \\
\hline 8 & $\left(1.622738 \times 10^{5}, 1.319951 \times 10^{6}\right)$ & 0.049357 & 0.027576 & $4.606748 \times 10^{5}$ \\
\hline 9 & $\left(1.879429 \times 10^{5}, 1.450162 \times 10^{6}\right)$ & 0.060226 & 0.064381 & $4.850213 \times 10^{5}$ \\
\hline 10 & $\left(1.464657 \times 10^{4}, 8.333579 \times 10^{4}\right)$ & 0.065406 & 0.057684 & $3.618402 \times 10^{4}$ \\
\hline
\end{tabular}

Sample estimate represents the variance ratio in the sample. $\hat{a}$ and $\hat{z}_{0}$ respectively represent the acceleration constant and bias correction constant. The number of resamplings is 3000 .

investment rates that show low international capital mobility is likely to have the property of moderate capital volatility (interpreted in terms of the location of the confidence intervals).

The lower panel of Table 17 shows the $95 \%$ confidence intervals of the relative variances between investment and savings rates for period II of OECD countries. Comparison of the results presented in this table with those of the lower panel of Table 15 shows that the increase in capital mobility can be interpreted as having come out with the increase in the relative volatility of capital transfers. Based on estimates presented in the lower panels of Table 15 and Table 17, international capital transfers among OECD countries became more mobile and volatile during 1997-2015 than during 1968-1996.

The empirical findings of the present study for period II of OECD countries 
are relevant primarily to the period after the euro zone was established within the OECD countries. The unified goods and services markets are designated in the literature as the necessary condition for mobile capital flows ([6] [20] [21] [22]). The results presented in the lower panel of Table 15 are apparently consistent with this view. If the sources of investment funds are in both the domestic and foreign financial markets, then the investment rate is presumed to have a wider range of fluctuation than the domestic savings rate. The increase in relative volatility of investment and savings rates presented in the lower panel of Table 17 can be understood in terms of increased mobility of international capital flows.

\subsection{Relative Volatility: Japan}

The upper panel of Table 18 shows the $95 \%$ confidence intervals of the relative

Table 18. 95\% BCa Confidence interval of variance ratio.

\begin{tabular}{|c|c|c|c|c|}
\hline \multicolumn{5}{|c|}{ Japan (Private investment, 1975-1997. $N=47, T=23, N T=1081$ ) } \\
\hline No. of Factors & Confidence interval & $\hat{a}$ & $\hat{z}_{0}$ & Sample estimate \\
\hline 1 & $\left(1.4479014 \times 10^{7}, 5.1791835 \times 10^{7}\right)$ & 0.004979 & 0.007520 & $2.6883599 \times 10^{7}$ \\
\hline 2 & $\left(6.134741 \times 10^{6}, 1.9737105 \times 10^{7}\right)$ & 0.010534 & 0.009191 & $1.0616655 \times 10^{7}$ \\
\hline 3 & $\left(4.105439 \times 10^{6}, 1.4887290 \times 10^{7}\right)$ & 0.010364 & 0.048480 & $7.393724 \times 10^{6}$ \\
\hline 4 & $\left(4.041002 \times 10^{6}, 1.4648437 \times 10^{7}\right)$ & 0.011189 & 0.028412 & $7.363715 \times 10^{6}$ \\
\hline 5 & $\left(3.804580 \times 10^{6}, 1.3159584 \times 10^{7}\right)$ & 0.005015 & 0.035936 & $6.848049 \times 10^{6}$ \\
\hline 6 & $\left(3.412609 \times 10^{6}, 1.0158325 \times 10^{7}\right)$ & 0.026330 & 0.027576 & $5.556488 \times 10^{6}$ \\
\hline 7 & $\left(1.268276 \times 10^{6}, 3.958918 \times 10^{6}\right)$ & 0.025302 & 0.035936 & $2.077083 \times 10^{6}$ \\
\hline 8 & $\left(2.627911 \times 10^{5}, 8.204337 \times 10^{5}\right)$ & -0.007188 & 0.005849 & $4.701394 \times 10^{5}$ \\
\hline 9 & $\left(2.461385 \times 10^{5}, 8.021312 \times 10^{5}\right)$ & -0.011698 & -0.001671 & $4.400411 \times 10^{5}$ \\
\hline 10 & $\left(5.275496 \times 10^{3}, 1.733169 \times 10^{4}\right)$ & 0.024269 & 0.037608 & $9.004016 \times 10^{3}$ \\
\hline \multicolumn{5}{|c|}{ Indonesia (Aggregate investment, 1983-2012. $N=26, T=30, N T=780$ ) } \\
\hline No. of Factors & Confidence interval & $\hat{a}$ & $\hat{z}_{0}$ & Sample estimate \\
\hline 1 & $\left(3.616925 \times 10^{6}, 2.5156452 \times 10^{7}\right)$ & 0.027015 & 0.010027 & $1.1170684 \times 10^{7}$ \\
\hline 2 & $\left(4.066725 \times 10^{6}, 2.4025970 \times 10^{7}\right)$ & 0.036104 & 0.076108 & $1.0664150 \times 10^{7}$ \\
\hline 3 & $\left(1.234010 \times 10^{6}, 9.278018 \times 10^{6}\right)$ & 0.0422737 & -0.022562 & $3.976375 \times 10^{6}$ \\
\hline 4 & $\left(3.98564 \times 10^{5}, 4.153294 \times 10^{6}\right)$ & -0.007936 & -0.021726 & $1.670666 \times 10^{6}$ \\
\hline 5 & $\left(3.432702 \times 10^{5}, 3.042497 \times 10^{6}\right)$ & 0.020763 & -0.006684 & $1.176738 \times 10^{6}$ \\
\hline 6 & $\left(1.089530 \times 10^{4}, 1.123953 \times 10^{5}\right)$ & -0.025876 & 0.004178 & $4.358044 \times 10^{4}$ \\
\hline 7 & $\left(1.083587 \times 10^{4}, 8.107186 \times 10^{4}\right)$ & 0.026007 & 0.019219 & $3.387749 \times 10^{4}$ \\
\hline 8 & $\left(0.978277 \times 10^{4}, 7.450008 \times 10^{4}\right)$ & 0.025686 & -0.005849 & $3.350314 \times 10^{4}$ \\
\hline 9 & $\left(2.498625 \times 10^{2}, 2.614088 \times 10^{4}\right)$ & -0.065503 & -0.021726 & $1.230301 \times 10^{4}$ \\
\hline 10 & $\left(2.040828 \times 10^{2}, 4.1998890 \times 10^{3}\right)$ & -0.080965 & -0.040953 & $1.562534 \times 10^{2}$ \\
\hline
\end{tabular}

Sample estimate represents the variance ratio in the sample. $\hat{a}$ and $\hat{z}_{0}$ respectively represent the acceleration constant and bias correction constant. The number of resamplings is 3000 . 
volatility of private investment and total savings for Japan. The magnitudes of volatility presented there are similar to those in the lower panel of Table 17 for period II of the OECD countries. Correspondence between mobile capital transfers presented in Table 13 and the upper panel of Table 16, and the more volatile investment rate than the savings rate for Japanese regional data in the upper panel of Table 18 is consistent with the relation between mobility (Table 12 and the lower panel of Table 15) and volatility (the lower panel of Table 17) in OECD countries during 1997-2015.

\subsection{Relative Volatility: Indonesia}

The lower panel of Table 18 presents the $95 \%$ confidence intervals of the relative volatility of gross investments and savings rates for Indonesia. The magnitudes of the volatility exhibited there in this table resemble those for results obtained for Japanese regional data presented in the upper panel of Table 18, and resemble those found for the results for period II of OECD countries in the lower panel of Table 17. The correspondence between highly mobile and highly volatile capital flows in Japanese regions and in period II of OECD countries holds for Indonesian regional data for which intranational capital transfers are interpreted as being mobile in Table 14 and the lower panel of Table 16. In fact, the relative volatility of investment rates has much larger magnitude than the savings rates presented in the lower panel of Table 18. Based on estimates of the mobility and the relative volatility measures of investment and savings rates for period II OECD countries, and based on regional data of Indonesia and Japan, one might describe that the Feldstein-Horioka puzzle in OECD countries that have been detected empirically and then reported in the literature faded away during the recent period of 1997-2015, which is most readily characterized by the start of the common currency euro zone at the beginning of 1999.

\section{Conclusions}

The primary message of this paper is that the idiosyncratic components of investment and savings rates reveal no linear relation during the period after the formation of the euro zone for OECD countries. For the empirical methods described in this paper to be able to detect both the existence and fading of the Feldstein-Horioka puzzle, the observation periods of OECD countries must be divided into two. The two time periods addressed in this paper are 1968-1996 and 1997-2015. The epoch-making events by which goods market integration was attained to make international capital flows mobile were the formation of the EU (November 1993) and especially the formation of the common currency euro zone (January 1999). It is assumed that, based on the publicly announced prior information related to the new currency system, enterprises, individuals, and investors started behaving in the way that the common currency zone has already been established around two years before the system officially started taking place. 
In period I (1968-1996) OECD countries, the cointegration relation in the idiosyncratic components of investment and savings rates showed evidence of the F-H puzzle (Table 11). Cases of no cointegration between the two variables in period II (1997-2015) OECD countries (Table 12) strongly suggest that the puzzle has ceased to exist in recent years. Identical results were obtained from estimation of the confidence intervals of the correlation coefficients between the two variables (Table 15).

Test results found for cointegration relations in the common factors and idiosyncratic components of the two variables presented in the literature (Byrne et al. [11], Costantini and Gutierez [16], Drakos, Kouretas, and Vlamis [23]) are apparently the results of mixing of observations of two distinct natures across a long time period. During that period, important events were taking place to unify goods and services markets in the formation of EU and the euro zone. Some reports of the literature refer to the relation between unified goods markets and the existence of the puzzle (Blanchard and Giavazzi [6], Ford and Horioka [20], Obstfeld and Rogoff [21], Yasutomi and Horioka [22], Ginama, Hayakawa, and Kanmei [26]).

Regional data of Japan and Indonesia show similar results to those reported in the literature: intranational capital flows are mobile (Table 13, Table 14, and Table 16). Analyses of regional data have a role in presenting the evidence that test results showing no significant linear relation between the two relevant variables of investment and savings rates indicate mobile capital flows across intranational borders.

Domestic (and local) investments theoretically need not be limited by the magnitudes of domestic (and local) savings if capital flows are mobile across international (and intranational) borders. The relative volatility measure estimated as described herein can therefore be interpreted as a different measure of capital mobility in addition to the non-significant linear relation prevailing between investment and savings rates.

Two measures of the magnitudes of international capital flows for OECD countries showed a tendency to move together: when capital transfers become more mobile in one period than in the other period, then the investment rate becomes increasingly more volatile than the savings rate across the two time periods. This relation between the two measures can be generalized by comparison with the estimates of the two measures for the regional capital flows in Japan and Indonesia.

Regional data of Japan and Indonesia show both high capital mobility and high relative volatility of capital flows across intranational borders. The mobility (zero correlation, and no cointegration relation between investment and savings rates) measure related to the source of investment funds, foreign or domestic (or local) can theoretically be better interpreted by combination with the relative volatility of (domestic or local) investments and savings. That is to say, if investment can be financed by both domestic (or local) and foreign sources of funds, then 
the scale of fluctuation of domestic (or local) investments is not limited by the availability of domestic (or local) investment funds.

\section{Acknowledgements}

An earlier form of this paper was presented at the Singapore Economic Review Conference 2019 (August 2019), and HU-HUE-SMU Tripartite Conference on Econometrics (March 2018). The authors are grateful to the conference participants for their helpful comments. Anonymous referees of this journal gave us many helpful comments. Any shortcomings, however, are solely attributable to the authors.

For this research, the authors received no specific grant from a funding agency in the public or not-for-profit sector.

\section{Conflicts of Interest}

The authors have no conflict of interest, financial or otherwise, related to this study.

\section{References}

[1] Apergis, N. and Tsoumas, C. (2009) A Survey of the Feldstein-Horioka Puzzle: What Has Been Done and Where We Stand. Research in Economics, 63, 64-76. https://doi.org/10.1016/j.rie.2009.05.001

[2] Kitamura, Y. and Fujiki, H. (1995) Feldstein-Horioka Paradox Revisited. Monetary and Economic Studies, 13, 1-16.

[3] Krol, R. (1996) International Capital Mobility: Evidence from Panel Data. Journal of International Money and Finance, 15, 467-474. https://doi.org/10.1016/0261-5606(96)00014-9

[4] Coiteux, M. and Olivier, S. (2000) The Saving Retention Coefficient in the Long Run and in the Short: Evidence from Panel Data. Journal of International Money and Finance, 19, 535-548. https://doi.org/10.1016/S0261-5606(00)00014-0

[5] Jansen, W.J. (2000) International Capital Mobility: Evidence from Panel Data. Journal of International Money and Finance, 19, 507-511. https://doi.org/10.1016/S0261-5606(00)00015-2

[6] Blanchard, O. and Giavazzi, F. (2002) Current Account Deficits in the Euro Area: The End of the Feldstein-Horioka Puzzle. Brookings Papers on Economic Activities, 2, 147-186. https://doi.org/10.1353/eca.2003.0001

[7] Coakley, J., Fuertes, A. and Spagnolo, F. (2004) Is the Feldstein-Horioka Puzzle History? The Manchester School, 72, 569-590. https://doi.org/10.1111/j.1467-9957.2004.00409.x

[8] Chakrabarti, A. (2006) The Saving-Investment Relationship Revisited: New Evidence from Multivariate Heterogeneous Panel Co-Integration Analyses. Journal of Comparative Economics, 34, 402-419. https://doi.org/10.1016/j.jce.2006.02.001

[9] Fouquau, J., Hurlin, C. and Rabaud, I. (2008) The Feldstein-Horioka Puzzle: A Panel Smooth Transition Regression Approach. Economic Modelling, 25, 284-299. https://doi.org/10.1016/j.econmod.2007.06.008

[10] Giannone, D. and Lenza, M. (2009) The Feldstein-Horioka Fact. In: NBER International Seminar on Macroeconomics 2009, University of Chicago Press, Chicago, 
103-117. https://doi.org/10.1086/648699

[11] Byrne, J., Fazio, G. and Fiess, N. (2009) The Global Side of the Investment-Saving Puzzle. Journal of Money, Credit and Banking, 41, 1033-1040. https://doi.org/10.1111/j.1538-4616.2009.00244.x

[12] Bai, J. and Ng, S. (2004) A Panic Attack on Unit Roots and Cointegration. Econometrica, 72, 1127-1177. https://doi.org/10.1111/j.1468-0262.2004.00528.x

[13] Bohn, H. (2007) Are Stationarity and Co-Integration Restrictions Really Necessary for the Intertemporal Budget Constraint? Journal of Monetary Economics, 54, 1837-1847. https://doi.org/10.1016/j.jmoneco.2006.12.012

[14] Pedroni, P. (2004) Panel Cointegration: Asymptotic Theory and Finite Sample Properties of Pooled Time Series Tests with an Application to the PPP Hypothesis. Econometric Theory, 20, 597-625. https://doi.org/10.1017/S0266466604203073

[15] Younas, J. and Chakraborty, D. (2011) Globalization and the Feldstein-Horioka Puzzle. Applied Economics, 43, 2089-2096.

https://doi.org/10.1080/00036840903035985

[16] Costantini, M. and Gutierrez, L. (2013) Capital Mobility and Global Factor Shocks. Economics Letters, 120, 513-515. https://doi.org/10.1016/j.econlet.2013.06.008

[17] Breitung, J. and Pesaran, M.H. (2005) Unit Roots and Cointegration in Panels. Institute for Economic Policy Research Working Paper No. 05.32, 1-50.

[18] Bai, J. and Kao, C. (2005) On the Estimation and Inference of a Panel Cointegration Model with Cross-Sectional Dependence. Center for Policy Research, Working Paper No. 75, 1-26. https://doi.org/10.2139/ssrn.1815227

[19] Katsimi, M. and Zoega, G. (2016) European Integration and the Feldstein-Horioka Puzzle. Oxford Bulletin of Economics and Statistics, 78, 834-852.

https://doi.org/10.1111/obes.12130

[20] Ford, N. and Horioka, C.Y. (2017) The "Real" Explanation of the Feldstein-Horioka Puzzle. Applied Economics Letters, 24, 95-97.

https://doi.org/10.1080/13504851.2016.1164814

[21] Obstfeld, M. and Rogoff, K. (2000) The Six Major Puzzles in Macroeconomics: Is There a Common Cause? MBER Macroeconomics Annual 2000, Vol. 15, 339-412. https://doi.org/10.1086/654423

[22] Yasutomi, A. and Horioka, C.Y. (2011) Adam Smith's Answer to the Feldstein-Horioka Paradox: The Invisible Hand Revisited. Economics Letters, 110, 36-37.

https://doi.org/10.1016/j.econlet.2010.09.018

[23] Drakos, A.A., Kouretas, G.P. and Vlamis, P. (2018) Saving, Investment and Capital Mobility in EU Member Countries: A Panel Data Analysis of the Feldstein-Horioka Puzzle. Applied Economics, 50, 3798-3811. https://doi.org/10.1080/00036846.2018.1436150

[24] Choi, I. (2006) Combination Unit Root Tests for Cross-Sectionally Correlated Panels. In: Corbae, D., Durlauf, S.N. and Hansen, B.E., Eds., Econometric Theory, and Practice: Frontiers of Analysis and Applied Research: Essays in Honor of Peter C.B. Phillips, Cambridge University Press, Cambridge, 311-333.

https://doi.org/10.1017/CBO9781139164863.014

[25] Choi, I. (2002) Combination Unit Root Tests for Cross-Sectionally Correlated Panels, Mimeo. Hong Kong University of Science and Technology, Hong Kong.

[26] Ginama, I., Hayakawa, K. and Kanmei, T. (2018) Examining the Feldstein-Horioka Puzzle Using Common Factor Panels and Interval Estimation. Japan and the World Economy, 48, 11-21. https://doi.org/10.1016/j.japwor.2018.06.001 
[27] Moon, H.R. and Weidner, M. (2015) Linear Regression for Panel with Unknown Number of Factors as Interactive Fixed Effects. Econometrica, 83, 1543-1579. https://doi.org/10.3982/ECTA9382

[28] Sinn, S. (1991) Measuring International Capital Mobility: A Critical Assessment of the Use of Saving and Investment Correlations. Kiel Working Papers 458, Kiel Institute for the World Economy, Kiel, 1-29.

[29] Bayoumi, T.A. and Rose, A.K. (1993) Domestic Saving and Intra-National Capital Flows. European Economic Review, 37, 1197-1202. https://doi.org/10.1016/0014-2921(93)90130-3

[30] Thomas, A. (1993) Saving, Investment, and the Regional Current Account: An Analysis of Canadian, British, and German Regions. IMF Working Paper, International Monetary Fund, Washington DC, 1-19. https://doi.org/10.5089/9781451848212.001

[31] Yamori, N. (1995) The Relationship between Domestic Savings and Investment: The Feldstein-Horioka Test Using Japanese Regional Data. Economics Letters, 48, 361-366. https://doi.org/10.1016/0165-1765(94)00616-A

[32] Dekle, R. (1996) Saving-Investment Associations and Capital Mobility: On the Evidence from Japanese Regional Data. Journal of International Economics, 41, 53-72. https://doi.org/10.1016/S0022-1996(96)01426-2

[33] Feldstein, M. and Horioka, C. (1980) Domestic Saving and International Capital Flows. Economic Journal, 90, 314-329. https://doi.org/10.2307/2231790

[34] Frankel, J., Dooley, M. and Mathieson, D. (1987) International Capital Mobility in Developing Countries vs. Industrial Countries: What Does Saving-Investment Correlation Tell Us? NBER Working Paper No. 2043. https://doi.org/10.3386/w2043

[35] Feldstein, M. (1983) Domestic Saving and International Capital Movements in the Long Run and the Short Run. European Economic Review, 21, 129-151. https://doi.org/10.1016/S0014-2921(83)80012-9

[36] Frankel, J. (1992) Measuring International Capital Mobility: A Review. American Economic Review, 82, 197-202.

[37] Summers, L. (1988) Tax Policy and Competitiveness. In: Frankel, J., Ed., International Aspects of Fiscal Policy, University of Chicago Press, Chicago, 349-375.

[38] Obstfeld, M. (1986) Capital Mobility in the World Economy: Theory and Measurement. Carnegie Rochester Conference Series on Public Policy, Vol. 24, 54-104. https://doi.org/10.1016/0167-2231(86)90005-9

[39] Obstfeld, M. (1993) International Capital Mobility in the 1990s. NBER Working Paper Series No. 4534, 1-75. https://doi.org/10.3386/w4534

[40] Iwamoto, Y. and Wincoop, E.V. (2000) Do Borders Matter? Evidence from Japanese Regional Net Capital Flows. International Economic Review, 41, 241-269. https://doi.org/10.1111/1468-2354.00063

[41] Bai, J. and Ng, S. (2002) Determining the Number of Factors in Approximate Factor Models. Econometrica, 70, 191-221. https://doi.org/10.1111/1468-0262.00273

[42] Bai, J. (2003) Inferential Theory for Factor Models of Large Dimensions. Econometrica, 71, 135-171. https://doi.org/10.1111/1468-0262.00392

[43] Onatski, A. (2010) Determining the Number of Factors from Empirical Distribution of Eigenvalues. The Review of Economics and Statistics, 92, 1004-1016. https://doi.org/10.1162/REST a 00043

[44] Gengenbach, C., Palm, F.C. and Urbain, J.P. (2006) Cointegration Testing in Panels with Common Factors. Oxford Bulletin of Economics and Statistics, 68, 683-719. 
https://doi.org/10.1111/j.1468-0084.2006.00452.x

[45] Levin, A., Lin, C.F. and Chu, C.S.J. (2002) Unit Root Tests in Panel Data: Asymptotic and Finite-Sample Properties. Journal of Econometrics, 108, 1-24.

https://doi.org/10.1016/S0304-4076(01)00098-7

[46] Im, K.S., Pesaran, M.H. and Shin, Y. (2003) Testing for Unit Roots in Heterogeneous Panels. Journal of Econometrics, 115, 53-74. https://doi.org/10.1016/S0304-4076(03)00092-7

[47] Maddala, G.S. and Wu, S. (1999) A Comparative Study of Unit Root Tests with Panel Data and a New Simple Test. Oxford Bulletin of Economics and Statistics, 61, 631-652. https://doi.org/10.1111/1468-0084.61.s1.13

[48] Hadri, K. (2000) Testing for Stationarity in Heterogeneous Panel Data. Econometrics Journal, 3, 148-161. https://doi.org/10.1111/1368-423X.00043

[49] Pedroni, P. (1999) Critical Values for Cointegration Tests in Heterogeneous Panels with Multiple Regressors. Oxford Bulletin of Economics and Statistics, 61, 653-670. https://doi.org/10.1111/1468-0084.61.s1.14

[50] Kao, C. (1999) Spurious Regression and Residual-Based Tests for Cointegration in Panel Data. Journal of Econometrics, 90, 1-44. https://doi.org/10.1016/S0304-4076(98)00023-2

[51] Efron, B. (1981) Nonparametric Estimates of Standard Error: The Jackknife, the Bootstrap and Other Methods. Biometrika, 68, 589-599.

https://doi.org/10.1093/biomet/68.3.589

[52] Efron, B. (1987) Better Bootstrap Confidence Intervals. Journal of the American Statistical Association, 82, 171-200. https://doi.org/10.1080/01621459.1987.10478410

[53] Efron, B. and Tibshirani, R. (1986) Bootstrap Methods for Standard Errors, Confidence Intervals, and Other Measure of Statistical Accuracy. Statistical Science, 1, 54-75. https://doi.org/10.1214/ss/1177013815

[54] Efron, B. and Tibshirani, R. (1998) An Introduction to the Bootstrap. Chapman and Hall/CRC, London.

[55] Good, P. (2005) Permutation, Parametric, and Bootstrap Tests of Hypotheses. Third Edition, Springer, Berlin.

[56] Manly, B. (2007) Randomization, Bootstrap and Monte Carlo Methods in Biology. Third Edition, Chapman and Hall/CRC, London.

[57] OECD (1998) National Accounts of OECD Countries, Volume 1: Main Aggregates, 1960-1996. OECD Publishing, Paris.

[58] OECD (2009) National Accounts of OECD Countries, Volume 1: Main Aggregates, 1996-2007. OECD Publishing, Paris.

[59] OECD (2015) National Accounts of OECD Countries, Volume 2015 Issue 1: Main Aggregates, 2007-2014. OECD Publishing, Paris.

[60] OECD (2017) National Accounts of OECD Countries, Volume 2017 Issue 1: Main Aggregates, 2008-2015. OECD Publishing, Paris.

[61] Badan Pusat Statistik (2014) The Government of Indonesia, Gross Regional Domestic Product of Provinces in Indonesia by Expenditure 1983-1991, 1987-1992, 1993-1996, 1997-2000, 1999-2002, 2000-2003, 2001-2005, 2002-2006, 2004-2008, 2005-2009, 2006-2010, 2007-2011, 2008-2012, 2009-2013.

[62] Choi, I. and Jeong, H. (2019) Model Selection for Factor Analysis: Some New Criteria and Performance Comparisons. Econometric Reviews, 38, 577-596. https://doi.org/10.1080/07474938.2017.1382763 
[63] Greenway-Mcgrevy, R., Han, C. and Sul, D. (2007) Estimating and Testing Idiosyncratic Equations Using Cross-Section Dependent Panel Data: Application to Feldstein-Horioka Puzzle, Mimeo. 